\title{
Isolation and pharmacological activities of the Tecoma stans alkaloids
}

\author{
Luca Costantino ${ }^{\mathrm{a}, *}$, Laura Raimondi ${ }^{\mathrm{b}}$, Renato Pirisino ${ }^{\mathrm{b}}$, Tiziana Brunetti ${ }^{\mathrm{c}}$, \\ Pompeo Pessotto ${ }^{c}$, Fabio Giannessi ${ }^{c}$, Arlete Paulino Lins ${ }^{a}$, Daniela Barlocco ${ }^{\mathrm{d}}$, \\ Luciano Antolini ${ }^{\mathrm{e}}$, Samia A. El-Abady ${ }^{\mathrm{f}}$ \\ ${ }^{a}$ Dipartimento di Scienze Farmaceutiche, Università di Modena e Reggio Emilia, Via Campi 183, I-41100 Modena, Italy \\ ${ }^{\mathrm{b}}$ Dipartimento di Farmacologia Preclinica e Clinica, Università di Firenze, Viale Pieraccini 6, I-50134 Firenze, Italy \\ ${ }^{\mathrm{c}}$ Departments of Chemical and Endocrinology and Metabolism Research, Sigma-Tau Pharmaceutical Industries S.p.A., Pomezia (Rome), Italy \\ ${ }^{\mathrm{d}}$ Istituto Chimico Farmaceutico e Tossicologico, Viale Abruzzi 42, 20131 Milan, Italy \\ e Dipartimento di Chimica, Università di Modena e Reggio Emilia, Via Campi 183, I-41100 Modena, Italy \\ ${ }^{\mathrm{f}}$ Department of Chemistry, University College for Girls, Ain Shams University, Heliopolis, Cairo, Egypt
}

Received 22 November 2002; accepted 4 February 2003

\begin{abstract}
Tecoma stans is a plant traditionally used in Mexico for the control of diabetes. Amongst the alkaloids isolated from the plant harvested in Egypt, Tecomine was shown to be one of the compounds responsible for the hypoglycemic action. Given the interest in substances able to treat type II diabetes, we isolated the main alkaloids present in the plant growing in Egypt and Brazil and tested them in vivo on $d b / d b$ mice. Contrary to previous literature reports on different animal models, Tecomine was unable to modify glycemia; the only effect seen being a decrease in plasma cholesterol levels. On the contrary, when tested in vitro on glucose uptake in white adipocytes, the compound showed a marked effect. The two other alkaloids isolated, namely $5 \beta$-Hydroxyskitanthine, early called Base $\mathrm{C}$, and Boschniakine were inactive both in vivo and in vitro assays.

(C) 2003 Éditions scientifiques et médicales Elsevier SAS. All rights reserved.
\end{abstract}

Keywords: Tecoma stans; Alkaloids; Hypoglycaemic activity

\section{Introduction}

Tecoma stans, a bush common to Latin America, is a plant traditionally used in Mexico for the control of diabetes. According to these folk reports, it has been shown recently that the plant extract is able to reduce the area under glucose tolerance curve in normal rabbits [1]. Moreover, intravenous administration of Tecoma stans leaves infusion in normal dogs was shown to produce an early hyperglycemic response followed by a slow decrease of the glucose blood values with a concomitant hypertriglyceridemia; no important changes in insuline levels were noted [2]. It is known that this plant contains monoterpene alkaloids, and two of these are apparently responsible for the hypoglycae-

\footnotetext{
* Corresponding author.

E-mail address: costantino.luca@unimo.it (L. Costantino).
}

mic activity of the plant. In fact, Tecomine $\mathbf{1}$ and Tecostanine 2, isolated from Tecoma stans growing in Egypt, were shown to produce a marked reductions in the blood sugar of fasting rabbits (normal or alloxantreated animals) both orally or i.v.; the mechanism of action of these substances was not elucidated, but they showed to be inactive in the absence of pancreas [3,4]. Recently, Tecostanine $\mathbf{2}$ was shown to be inactive as hypoglycemic agent in normoglycemic and hyperglycemic rats [5]. Given the great interest in novel agents able to treat diabetes, we have now investigated the effect on an in vivo model of genetic diabetes ( $d b / d b$ mouse) of Tecomine $\mathbf{1}$ and of the two other alkaloids that are present in large quantities in both the plants we collected from Egypt and Brazil, namely $5 \beta$-Hydroxyskitanthine (3), early called Base C, and Boschniakine (4), which at the best of our knowledge, had never been tested as antidiabetic agents. A parallel in vitro study on adipo- 
cyte glucose uptake was also performed on compounds 1,3 and 4.

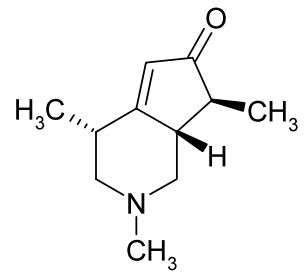

1 = Tecomine

$1 \mathbf{a}=$ Tecomine $\mathrm{HCl}$<smiles>C[C@@H]1CC[C@]2(O)[C@@H]1CN(C)C[C@H]2C</smiles>

$3=5 \beta$ Hydroxyskitanthine (Base $\mathrm{C}$ ) $\mathbf{3 b}=5 \beta$ Hydroxyskitanthine $(\mathrm{COOH})_{2}$

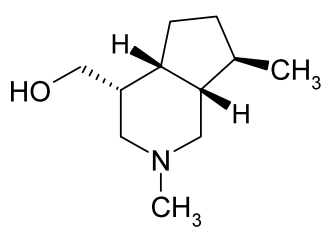

2 = Tecostanine

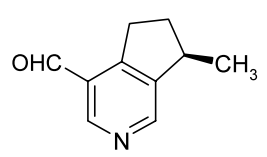

4 = Boschniakine $4 \mathrm{a}=$ Boschniakine $(\mathrm{COOH})_{2} \cdot 0.5 \mathrm{H}_{2} \mathrm{O}$

\section{Results and discussion}

It is known that Tecoma stans possesses a great variability in its alkaloidic composition depending on the place of growth, Tecomine $\mathbf{1}$ being present in all the samples examined [6]. We determined the composition of the alkaloidic fraction of the plant collected in Egypt and in another country, Brazil, in order to find substance(s) that could be useful for the treatment of type II diabetes. The plant collected in Egypt showed a gas chromatography (GC) of the alkaloidic fraction in which 3 is $11.37 \%$ of the area of the entire chromatogram (RT $16.95 \mathrm{~min}$ ), $\mathbf{4}$ is $17.30 \%$ (RT $18.59 \mathrm{~min}$ ), $\mathbf{1}$ is $10.40 \%$ (RT $18.93 \mathrm{~min}$ ), and Tecostanine 2 is $21.88 \%$ (RT $19.13 \mathrm{~min}$ ) (total $60.90 \%$ area of the entire chromatogram); the plant from Brazil shows for $\mathbf{3}$ $11.77 \%$, for $424.89 \%$, for $\mathbf{1} 11.48 \%$ and Tecostanine 2 is $3.69 \%$ (total $51.83 \%$ of the entire chromatogram), thus confirming the variability of the composition of the alkaloidic fraction of this plant. According to the GC analysis, we were able to isolate from the crude alkaloidic fraction in appreciable quantity only compounds 1, 3 and $\mathbf{4}$ (besides Tecostanine $\mathbf{2}$ from the plant collected in Egypt [5]).

All the isolated alkaloids were tested on $d b / d b$ mice, a genetic model of type II diabetes characterized by insulin resistance and obesity. In particular, the Tecomine hydrochloride (1a), the 5 3 -Hydroxyskitanthine oxalate (3b) and the Boschniakine oxalate hemihydrate (4a) were administered at the following doses: $\mathbf{1 a}$ and $\mathbf{4 a}$ at the dose of $50 \mathrm{mg} / \mathrm{kg}$ p.o.; $3 \mathbf{b}$ at the dose of $63.4 \mathrm{mg} /$ $\mathrm{kg}$ p.o. Contrary to what previously reported for $\mathbf{1}$ on different animal models, none of the compounds proved able to significantly reduce plasma glycemia or insulin levels after 2 or $7 \mathrm{~h}$ from the treatment. In the same experimental setting, Rosiglitazone, at the dose of $5 \mathrm{mg} /$ $\mathrm{kg}$ p.o., was able to reduce glycemia $(372.6 \pm 21.6 \mathrm{mg} / \mathrm{dl}$ versus control $621.0 \pm 36.1)$. However, it should be noted that compound 1a reduced plasma cholesterol levels $(72.96 \mathrm{mg} / \mathrm{dl} \pm 4.08$ (SE) versus control $(94.48 \pm$ 3.63 (SE), $P<0.02$ ) while body weight, free fatty acids, triglycerides and urea, as well as food and water intake did not change following the treatment.

It is possible that pharmacokinetic factors or a different sensitivity of the animal species considered can affect the in vivo activity of $\mathbf{1}$.

This hypothesis seems to be supported by the results of a parallel in vitro study which showed that Tecomine 1 exerts a potent stimulating effect on the basal glucose uptake rate in rat adipocytes from normoglycemic rats, with an $\mathrm{EC}_{50}$ value of $6.79 \times 10^{-9} \mathrm{M}$. On the contrary, the two other alkaloids tested $(\mathbf{3}, \mathbf{4})$ were inactive up to $100 \mu \mathrm{M}$.

More studies are thus needed in order to assess definitively the therapeutic interest of Tecomine for the treatment of diabetes.

\section{Experimental}

\subsection{Chemistry}

Melting points (m.p.) were determined on a Buchi melting point apparatus and are uncorrected. Optical rotation was obtained on a Perkin-Elmer mod. 241 spectropolarimeter. ${ }^{1} \mathrm{H}(200 \mathrm{MHz})$ and ${ }^{13} \mathrm{C}(50 \mathrm{MHz})$ NMR spectra were recorded on a Bruker AMX-200 spectrophotometer. Chemical shifts are shown in ppm with TMS as internal standard; $J$ values are given in $\mathrm{Hz}$. IR spectra were recorded on a Perkin-Elmer FT-IR spectrophotometer mod. 1600. X-ray crystallography data were collected on a Enraf-Nonius CAD4 diffractometer. The GC analyses were carried out on a PerkinElmer mod sigma $3 \mathrm{~b}$ gas chromatograph, equipped with a flame ionisation detector, connected to a PerkinElmer nelson integrator mod 1022, using a capillary column (Hewlett-Packard, $25 \mathrm{~m} \times 0.31 \mathrm{~mm}$ i.d., film thickness $1.03 \mu \mathrm{m}$ ) cross-linked with $5 \%$ phenyl methyl silicone under the following conditions carrier gas $\mathrm{H}_{2}$, split ratio 90:10, injector and detector temperature $250{ }^{\circ} \mathrm{C}$ and column temperature programmed from $50{ }^{\circ} \mathrm{C}(5 \mathrm{~min})$ to $200{ }^{\circ} \mathrm{C}$ at $10{ }^{\circ} \mathrm{C} / \mathrm{min}$. Mass spectra of eluted peaks were obtained in the above experimental conditions by means of a mass spectrometer Finnigan Mat SSQ 710 equipped with a gas chromatograph Varian 3400 (Centro Interdipartimentale Grandi Strumenti, Modena University). Microanalyses were carried out in the Microanalysis Laboratory of the Dipartimento di Scienze Farmaceutiche, Modena University. 
Elemental analyses were within $\pm 0.4 \%$ of the theoretical values. Silica gel (Merck, 70-230 mesh) was used for column chromatography. Rosiglitazone was synthesized according to a published procedure [7] (Table 1).

\subsection{Plant material}

Leaves of Tecoma stans (Juss) (Bignoniaceae) growing in II Cairo, Egypt, or in Brazil (from San Paulo province) collected during July 1999 and November 1998, respectively, were used. A voucher specimen (LC2002/01 and LC2002/02, respectively) was deposited in the Herbarium of the Dipartimento di Scienze Farmaceutiche, Università di Modena e Reggio Emilia.

\subsection{Extraction procedure}

The dried leaves $(500 \mathrm{~g})$ were extracted (Soxhlet) with $\mathrm{Et}_{2} \mathrm{O} / \mathrm{NH}_{3} 15 \%(10 / 90 \mathrm{v} / \mathrm{v})(3 \mathrm{l})$. The organic layer was then extracted with $4 \mathrm{~N} \mathrm{HCl}(1000 \mathrm{ml})$; the aqueous phase was then washed with ether $(3 \times 200 \mathrm{ml})$, basified with $\mathrm{NH}_{3} 30 \%$ and extracted with $\mathrm{CH}_{2} \mathrm{Cl}_{2}(2 \times 500 \mathrm{ml})$. The organic layer was then dried $\left(\mathrm{Na}_{2} \mathrm{SO}_{4}\right)$ and the solvent removed under reduced pressure. The crude alkaloidic fraction thus obtained $(3 \mathrm{~g}$ from the plants harvested in Brazil or Egypt) was then chromatographed on silica gel with as mobile phase $\mathrm{CH}_{2} \mathrm{Cl}_{2}$ and increasing quantity of $\mathrm{CH}_{3} \mathrm{OH}$ (from 0 to $40 \%$ ). 4 was eluted at $2 \% \mathrm{CH}_{3} \mathrm{OH}$ (TLC mobile phase $\mathrm{CH}_{2} \mathrm{Cl}_{2} /$ $\mathrm{CH}_{3} \mathrm{OH} / \mathrm{NH}_{3} 89.5 / 10 / 0.5, R_{\mathrm{f}} 0.9$ ), 1 at 5\% (TLC, $R_{\mathrm{f}}$ $0.80), 3$ at $10 \%$ (TLC, $R_{\mathrm{f}} 0.29$ ).

\subsubsection{Tecomine (1)}

Yield $0.2 \mathrm{~g}$, oil; purity $(\mathrm{GC})>90 \%,[\alpha]_{\mathrm{D}}^{25}\left(\mathrm{CHCl}_{3}\right)$ : $-144^{\circ}(c=1) \quad\left([\alpha]_{\mathrm{D}}\left(\mathrm{CHCl}_{3}\right)-160^{\circ} \quad[8] ;{ }^{1} \mathrm{H}-\mathrm{NMR}\right.$ $\left(\mathrm{CDCl}_{3}\right): 1.17(3 \mathrm{H}, \mathrm{d}, J$ 6.7), $1.19(3 \mathrm{H}, \mathrm{d}, J$ 7.6), 1.78 $(2 \mathrm{H}, \mathrm{t}, J 11.1), 1.97(1 \mathrm{H}, \mathrm{qd}, J 7.6,3.1), 2.35(3 \mathrm{H}, \mathrm{s})$, $2.50-2.65(1 \mathrm{H}, \mathrm{m}), 2.70-2.80(1 \mathrm{H}, \mathrm{m}), 3.05(1 \mathrm{H}, \mathrm{ddd}, J$ $11.0,5.8,1.5), 3.28(1 \mathrm{H}$, ddd, $J 11.0,6.0,2.0), 5.90(1 \mathrm{H}$, $\mathrm{m})$, in accordance to Ref. [9]. MS $m / z 179\left(M^{+}, 100\right)$, 164 (22), 150 (20), 136 (22), 121 (22), 111 (30), 93 (27), 77 (12), 57 (70), in accordance to Ref. [9].

\subsubsection{Tecomine $\mathrm{HCl}(\mathbf{1 a})$}

M.p. $175-6{ }^{\circ} \mathrm{C}\left(\mathrm{CH}_{3} \mathrm{OH} / \mathrm{Et}_{2} \mathrm{O}\right) ;{ }^{1} \mathrm{H}$ NMR (DMSO$\left.d_{6}\right): 1.11(3 \mathrm{H}, \mathrm{d}, J 7.40), 1.18(3 \mathrm{H}, \mathrm{d}, J 6.58), 2.10(1 \mathrm{H}$, ddd, $J 10.03,7.31,2.69), 2.77(3 \mathrm{H}, \mathrm{s}), 2.78-3.30(4 \mathrm{H}$, $\mathrm{m}), 3.55(1 \mathrm{H}, \mathrm{m}), 3.80(1 \mathrm{H}, \mathrm{m}), 6.06(1 \mathrm{H}, \mathrm{m}), 11.71(1 \mathrm{H}$ broad s). Anal. $\mathrm{C}_{11} \mathrm{H}_{17} \mathrm{NO} \cdot \mathrm{HCl} \mathrm{C}, \mathrm{H}, \mathrm{N}$.

\subsection{3. $5 \beta$-Hydroxyskitanthine (3)}

Yield $0.4 \mathrm{~g}$, purity $(\mathrm{GC})>90 \% ;{ }^{1} \mathrm{H}$ NMR $\left(\mathrm{CDCl}_{3}\right)$ : $0.92(3 \mathrm{H}, \mathrm{d}, J 6.83), 1.18(3 \mathrm{H}, \mathrm{d}, J 6.89), 1.48-1.75(\mathrm{~m}$, $7 \mathrm{H}), 1.90-2.10(\mathrm{~m}, 2 \mathrm{H}), 2.24(\mathrm{~s}, 3 \mathrm{H}), 2.65$ (ddd, $J 10.2$, 4.5, 2.2), 2.79 (1H, ddd, $J 11.4,4.5,2.3) .{ }^{13} \mathrm{C}$ NMR: 13.1, 23.9, 30.4, 33.1, 36.9, 39.6, 45.6, 55.0, 60.3, 62.2, 83.0. MS $\mathrm{m} / \mathrm{z} 183\left(M^{+}, 90\right), 182(100), 166(30), 164$ (32), 150 (80), 122 (30), 108 (28), 98 (20), 84 (70), 74 (40), 58 (38), 57 (60), 55 (35). IR (Nujol) $\left(\mathrm{cm}^{-1}\right)$ : 3400 . (the spectra are in accordance with Ref. [10]). In order to confirm the structure, $\mathbf{3}$ was converted in its methiodide 3a and subjected to X-ray crystallography.

\subsection{4. $5 \beta$-Hydroxyskitanthine methiodide (3a)}

$5 \beta$-Hydroxyskitanthine $3(0.20 \mathrm{~g}, 1.10 \mathrm{mmol})$ was dissolved in anh. $\mathrm{Et}_{2} \mathrm{O}(5 \mathrm{ml}) ; \mathrm{CH}_{3} \mathrm{I}$ was added $(0.93 \mathrm{ml}$, $1.50 \mathrm{mmol}$ ) at room temperature (r.t.) under stirring. A white precipitate appeared immediately; the suspension was stirred for $3 \mathrm{~h}$, then the precipitate was collected, washed with $\mathrm{Et}_{2} \mathrm{O}$ and dried. Yield $0.22 \mathrm{~g}(62 \%)$, m.p. $293-5{ }^{\circ} \mathrm{C}\left(\mathrm{CH}_{3} \mathrm{OH}\right) ;{ }^{1} \mathrm{H}$ NMR (DMSO- $\left.d_{6}\right): 0.90(3 \mathrm{H}, \mathrm{d}$, $J$ 6.85), $1.17(3 \mathrm{H}, \mathrm{d}, J$ 6.83), $1.35-2.05(6 \mathrm{H}, \mathrm{m}), 2.43$ $(1 \mathrm{H}, \mathrm{m}), 2.90(1 \mathrm{H}, \mathrm{t}), 3.11(3 \mathrm{H}, \mathrm{s}), 3.12(3 \mathrm{H}, \mathrm{s}), 3.45(3 \mathrm{H}$, $\mathrm{m}), 4.45(1 \mathrm{H}, \mathrm{s})$. Crystals suitable for X-ray analysis were grown from a methanolic solution. The crystal structure is the same as reported [11], with the same cell parameters.

\subsection{5. $5 \beta$-Hydroxyskitanthine $(\mathrm{COOH})_{2}(3 \boldsymbol{b})$}

M.p. $158-60{ }^{\circ} \mathrm{C}\left(\mathrm{CH}_{3} \mathrm{OH} / \mathrm{Et}_{2} \mathrm{O}\right) ;{ }^{1} \mathrm{H}$ NMR (DMSO$\left.d_{6}\right): 0.89(3 \mathrm{H}, \mathrm{d}, J$ 6.85), $1.17(\mathrm{~d}, 3 \mathrm{H}, J$ 6.83), 1.35-2.05 $(\mathrm{m}, 6 \mathrm{H}), 2.15(\mathrm{~m}, 1 \mathrm{H}), 2.42-2.60(\mathrm{~m}, 4 \mathrm{H}), 2.67(\mathrm{~s}, 3 \mathrm{H})$, $3.23(\mathrm{~m}, 2 \mathrm{H}), 8.40\left(2 \mathrm{H}\right.$, broad s). Anal. $\mathrm{C}_{13} \mathrm{H}_{23} \mathrm{NO}_{5}$ : C, $\mathrm{H}, \mathrm{N}$.

\subsubsection{Boschniakine (4)}

Yield $0.7 \mathrm{~g}$, oil; purity (GC) $>96 \%,[\alpha]_{\mathrm{D}}^{25}\left(\mathrm{CHCl}_{3}\right)$ $+22.5^{\circ}(c=1)\left([\alpha]_{\mathrm{D}}+21^{\circ}\right.$ [8]; IR (Nujol) $\left(\mathrm{cm}^{-1}\right): 1697$; ${ }^{1} \mathrm{H}$ NMR $\left(\mathrm{CDCl}_{3}\right): 1.38(3 \mathrm{H}, \mathrm{d}, J 6.91), 1.60-1.84(1 \mathrm{H}$, m), 2.36-2.54 $(1 \mathrm{H}, \mathrm{m}), 3.00-3.48(3 \mathrm{H}, \mathrm{m}), 8.62(1 \mathrm{H}, \mathrm{s})$, $8.83(1 \mathrm{H}, \mathrm{s}), 10.23(1 \mathrm{H}, \mathrm{s})$, in accordance to Ref. [12];

Table 1

Elemental analyses

\begin{tabular}{lllll}
\hline Comp. & Formula & C Calc./found & H Calc./found & N Calc./found \\
\hline 1a & $\mathrm{C}_{11} \mathrm{H}_{17} \mathrm{NO} \cdot \mathrm{HCl}$ & $61.25 / 61.58$ & $8.41 / 8.33$ & $6.49 / 6.11$ \\
3b & $\mathrm{C}_{11} \mathrm{H}_{21} \mathrm{NO} \cdot(\mathrm{COOH})_{2}$ & $57.13 / 57.51$ & $8.48 / 8.33$ & $5.12 / 5.40$ \\
$\mathbf{4 a}$ & $\mathrm{C}_{10} \mathrm{H}_{11} \mathrm{NO} \cdot(\mathrm{COOH})_{2} \cdot 0.5 \cdot \mathrm{H}_{2} \mathrm{O}$ & $55.38 / 55.33$ & $5.42 / 5.18$ & $5.38 / 5.50$ \\
\hline
\end{tabular}


MS $m / z 161\left(M^{+}, 100\right), 160(30), 146(80), 132(40), 117$ (57), 91 (22), 77 (19), 65 (10), 51 (10).

\subsubsection{Boschniakine $(\mathrm{COOH})_{2} \cdot 0.5 \cdot \mathrm{H}_{2} \mathrm{O}(4 \mathrm{a})$}

M.p. $113-6{ }^{\circ} \mathrm{C}\left(\mathrm{CH}_{3} \mathrm{OH} / \mathrm{Et}_{2} \mathrm{O}\right) ;{ }^{1} \mathrm{H}$ NMR (DMSO$\left.d_{6}\right): 1.31(3 \mathrm{H}, \mathrm{d}, J 6.90), 1.55-1.70(\mathrm{~m}, 1 \mathrm{H}), 2.30-2.45$ $(\mathrm{m}, 1 \mathrm{H}), 3.00-3.15(1 \mathrm{H}, \mathrm{m}), 3.19(1 \mathrm{H}, \mathrm{s}), 3.20-3.30(2 \mathrm{H}$, m), $8.68(1 \mathrm{H}, \mathrm{s}), 8.86(1 \mathrm{H}, \mathrm{s}), 10.21(1 \mathrm{H}, \mathrm{s})$. Anal. $\mathrm{C}_{12} \mathrm{H}_{13} \mathrm{NO}_{5} \cdot 0.5 \cdot \mathrm{H}_{2} \mathrm{O}: \mathrm{C}, \mathrm{H}, \mathrm{N}$.

\subsection{Pharmacology}

\subsubsection{Glucose uptake in Wistar rats white adipocytes}

3.4.1.1. Animals. Male Wistar rats (180-200 g) were obtained from Charles-River Italy breeding colonies. The animals were housed at $23 \pm 1{ }^{\circ} \mathrm{C}$ with a $12 \mathrm{~h}$ lightdark cycle, light on at 07:00 $\mathrm{h}$ and were fed a standard laboratory diet with water ad libitum. All the experiments were carried out in accordance with the European Communities Council Directive of 24 November 1986 (86/609/EEC) for experimental animal care.

3.4.1.2. Adipocyte preparation. Adipocytes were prepared according to Rodbell [13]. The epidydymal fat pads were removed and placed in oxygenated cold Krebs bicarbonate buffer $\mathrm{pH} 7.5$ of the following composition (mM): $\mathrm{NaHCO}_{3}$ (25), glucose (11.1), $\mathrm{NaCl}$ (118), $\mathrm{KCl}$ (4.7), $\mathrm{KH}_{2} \mathrm{PO}_{4}$ (1.2), $\mathrm{MgSO}_{4}$ (0.6). The tissue was then minced with scissors and digested for $40-60 \mathrm{~min}$ at $37^{\circ} \mathrm{C}$ in Krebs buffer containing collagenase $(0.5 \mathrm{mg} / \mathrm{ml}$; type I, Sigma) and $2 \%$ free fatty acid bovine serum albumin (SIGMA). After digestion the tissue was filtered on a nylon gauze and washed extensively with warm Krebs buffer. Adipocytes were then concentrated and counted. An average amount of $300.000-400.000$ cells/tube were used.

3.4.1.3. Glucose uptake. Glucose uptake was measured in floating, viable, adipocytes using the non metabolisable analogue of glucose, the ${ }^{3} \mathrm{H}$-2-deoxy-D-glucose $(100 \mu \mathrm{M}, 0.2 \mu \mathrm{Ci} / \mathrm{ml})$.

Cells were first pre-incubated for $10 \mathrm{~min}$ at $37{ }^{\circ} \mathrm{C}$ in atmosphere of $5 \% \mathrm{CO}_{2}$ before the addition of the pharmacological stimuli. Insulin $(10 \mathrm{nM}$, Sigma $)$ or the tested compounds were then added to cell suspensions and incubated for 45 or $10 \mathrm{~min}$, respectively before the addition of the labelled compound.

Glucose uptake was evaluated after $10 \mathrm{~min}$ from the addition of the ${ }^{3} \mathrm{H}$-2-deoxy-D-glucose $(100 \mu \mathrm{M}, 0.2 \mu \mathrm{Ci} /$ $\mathrm{ml})$. At that time Phloretin ( $200 \mu \mathrm{M}$; Sigma) was added to each tube. Cells were then filtered on nitrocellulose filter ( $8 \mu \mathrm{M}$; Sartorius) under light vacuum. After three washings with cold Krebs buffer, the filters were dried up at r.t. and placed in a vials containing Filter-Count (Packard). The radioactivity was measured using a $\beta$ - counter. Basal uptake was completely abolished by the use of Phloretin $(200 \mu \mathrm{M})$, whereas the insulin-dependent uptake was inhibited by more than $80 \%$ by using Cytocalasin $(20 \mu \mathrm{M})$.

Results are expressed as nmoles of deoxy-glucose $/ 10^{6}$ cells or as the ratio between the uptake measured in stimulated cells over that measured in cells without any treatment (basal uptake).

Stock solutions $(1 \mathrm{mM})$ of the compounds $\mathbf{1}, \mathbf{3}$ and $\mathbf{4}$ (as free bases) were prepared in DMSO. At the concentrations used, DMSO (maximum tested $0.01 \%$ ) had no effect on glucose uptake. Results are the mean \pm SE of four different exp. run in duplicate. Basal uptake: $1.27 \pm 0.22 \mathrm{nmol} / 10^{6}$ cells $/ 10 \mathrm{~min}$.

\subsubsection{In vivo antidiabetic assays}

Male C57BL/KsJ $d b / d b$ mouse ( 8 weeks old) were used. Six animals were used for control and for the compounds to be assayed. Mouse were treated p.o. twice each day (at 08:30 and 18:30 h) for 7 days by gavage at the dose of $50 \mathrm{mg} / \mathrm{kg}$ in C.M.C. (1\%) and Tween 80 $(0.5 \%)(10 \mathrm{ml} / \mathrm{kg})$ for $1 \mathrm{a}$ and $4 \mathrm{a} ; 63.4 \mathrm{mg} / \mathrm{kg}$ were used for $\mathbf{3 b}$; Rosiglitazone was used as a reference compound at the dose of $5 \mathrm{mg} / \mathrm{kg}(10 \mathrm{ml} / \mathrm{kg})$, p.o.; then they were sacrificed at 7 th day after $7 \mathrm{~h}$ from the last treatment and the following parameters were determined: plasma glucose (evaluated by Kit glucose GDH, Roche), triglycerides, cholesterol and urea (by Kits Roche), free fatty acids (by Kit NEFA C, Wako). Plasma insulin was assessed by Kit ${ }^{125}$ I-Rat insulin (Amersham). Controls received only vehicle $(10 \mathrm{ml} / \mathrm{kg})$.

\section{Acknowledgements}

We thank Professor Dr M. Hammouda, Department of Botany, University College for Girls, Ain Shams University, Heliopolis, Cairo, Egypt, for kindly providing the plant material.

\section{References}

[1] R. Roman Ramos, J.L. Flores Saenz, G. Partida Hernandez, A. Lara Lemus, F. Alarcon Aguillar, Experimental study of the hypoglycemic effect of some antidiabetic plants, Arch. Invest. Med.(Mex) 22 (1991) 87-93.

[2] M. Loyoza Meckes, V. Mellado-Campos, Is the Tecoma stans tnfusion an antidiabetic remedy?, J. Ethnopharmacol. 14 (1985) $1-9$.

[3] Y. Hammouda, M.S. Amer, Antidiabetic effect of Tecomine and Tecostanine, J. Pharm. Sci. 55 (1966) 1452-1454.

[4] Y. Hammouda, A.K. Rashid, M.S. Amer, Hypoglycaemic properties of Tecomine and Tecostanine, J. Pharm. Pharmacol 16 (1964) 833-835

[5] L. Costantino, A.P. Lins, D. Barlocco, F. Celotti, S.A. El-Abady, T. Brunetti, R. Maggi, L. Antolini, Characterization and phar- 
macological actions of Tecostanine, an alkaloid of Tecoma stans, Die Pharmazie, in press.

[6] E.M. Dickinson, G. Jones, Pyrindane alkaloids from Tecoma stans, Tetrahedron 25 (1969) 1523-1529.

[7] B.C.C. Cantello, M.A. Cawthorne, D. Haigh, R. Hindley, S.A. Smith, P.L. Thurlby, The synthesis of BRL 49653-A novel and potent antihyperglycaemic agent, Bioorg. Med. Chem. Lett. 4 (1994) $1181-1184$.

[8] G.A. Cordell, The Monoterpene Alkaloids, in: R.H.F. Manske (Ed.), The Alkaloids, vol. 16, Academic Press, 1977, pp. 431-510.

[9] G. Vidari, M. Tripolini, P. Novella, P. Allegrucci, L. Garlaschelli, Desymmetrization of bicyclo[3.3.0]octane-3,7-dione by the Schmidt reaction: an easy synthesis of Tecomanine, Tetrahedron: Asymmetry 8 (1997) 2893-2903.
[10] J. Cossy, D. Belotti, C. Leblanc, Total synthesis of (+/-)Actinidine and of (+/-)-Isooxyskytanthine, J. Org. Chem. 58 (1993) 2351-2354.

[11] G. Ferguson, W.C. Marsh, Crystal structures and absolute stereochemistry of Tecomanine methoperchlorate and 'alkaloid C' methiodide: two monoterpene alkaloids from Tecoma stans, J. Chem. Soc. Perkin II (1975) 1124-1128.

[12] Y. Imakura, S. Kobayashi, Y. Yamahara, M. Kihara, M. Tagawa, F. Murai, Studies on costituents of bignoniaceae plants. IV. Isolation and structure of a new iridoid glucoside, campsiside, from Campsis chinensis, Chem. Pharm. Bull. 32 (1985) 22202227.

[13] M. Rodbell, Metabolism of isolated fat cells, J. Biol. Chem. 239 (1964) 375-380. 